\title{
STRATEGI PENGEMBANGAN \\ MANAJEMEN PESERTA DIDIK DALAM MENINGKATKAN MUTU PENDIDIKAN DI MTsN PADANG PANJANG
}

\author{
Akmal Firdaus $^{1}$, Aslinda $^{2}$ \\ ${ }^{1}$ Guru MAN 3 Padang Panjang, ${ }^{2}$ Guru MTsN Padang Panjang \\ Korespondensi: Jalan Rasuna Said No. 14 Padang Panjang \\ e-mail: ${ }^{1}$ akmalfirdaus1912@gmail.com, ${ }^{2}$ aslinda20031973@gmail.com
}

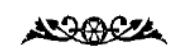

\begin{abstract}
The strategy of development student management is needed by every educational institution in improving the quality of its students. This study aims to know the strategies carried out by MTsN Padang Panjang in the acceptance of new students, the orientation has been done to new students and the management that is applied in coaching as an effort to improve the quality of education in Padang Panjang MTsN. The methodology of research is qualitative in form of the case study research. The research findings show that MTsN Padang Panjang implements a strategy of accepting new students with relatively rigorous selection by combining modern and conservative management. Among the strategies implemented is by registering prospective students on line. The new student orientation strategy is known from the implementation of Matsama (Students Introduction) which is more applying the religious approach, discipline and building togetherness. The strategy of coaching students is curricular and extracurricular. Curricular guidance is carried out in a structured, effective, and continuous manner, such as subject learning activities and the Qur'an recitation. Extracurricular coaching is carried out intensively, professionally, and continuously, such as additional learning, religious activities in dormitories and playing basketball.
\end{abstract}

Keywords: strategy, student management, quality of education

\section{PENDAHULUAN}

Strategi peningkatan kualitas dan pengembangan manajemen lembaga pendidikan Islam mutlak diperlukan, agar mampu bertahan dan mengembangkan diri dari era globalisasi ini. Strategi pendidikan tersebut pada dasarnya bertumpu pada kemampuan memperbaiki dan merumuskan visinya setiap zaman, dan kemudian dituangkan dalam rumusan tujuan pendidikannya yang jelas. Tujuan pendidikan tersebut selanjutnya dirumuskan dalam program pendidikan yang aplikatif, metode dan pendekatan yang tepat, guru yang berkualitas, kurikulum yang sesuai, serta sarana dan prasarana yang relevan dengan pencapaian tujuan pendidikan.

Manajemen pendidikan dalam lembaga pendidikan merupakan salah satu faktor penting yang dapat menentukan keberhasilan penyelenggaraan pendidikan (Zahroh, 2014: 147). Menurut Maimun dan Fitri (2013: 51-66), ada tujuh konsep dasar strategi pengembangan pendidikan di madrasah yaitu: (1) strategi pengembangan manajemen madrasah, (2) strategi pengembangan kurikulum, (3) strategi pengembangan pembelajaran, (4) strategi 
pengembangan layanan kepada siswa, (5) strategi pengembangan bakat dan minat, (6) strategi pengembangan lingkungan belajar, (7) strategi pengembangan sarana dan prasarana.

Hendriani, dkk (2019: 137), melakukan penelitian dengan judul "Pengarub Kecerdasan Emosional dan Kepemimpinan Terhadap Kepemimpinan Kepala Madrasah di Kabupaten Agam". Hasil penelitiannya menunjukkan bahwa kecerdasan emosi dan kepribadian memiliki pengaruh signifikan terhadap kepemimpinan kepala madrasah. Berdasarkan penelitian tersebut, maka pengembangan kualitas madrasah dapat dilakukan melalui peningkatan kompetensi kepribadian dan emosi kepala madrasah.

Asmendri, dkk (2019), melakukan penelitian dengan judul "Manajemen Prinsip Madrasah di MA KMM Kauman Padang Panjang Dalam Melaksanakan Program Adiwiyata". Menurut peneliti, permsalahan yang terjadi di sekolah dapat ditanggulangi di antaranya dengan manajemen yang tepat. Permasalahan sekolah di antaranya adalah masalah kerusakan lingkungan. Hasil penelitian ini menunjukkan bahwa fungsi manajemen dalam pelaksanaan program Adiwiyata dilakukan dengan perencanaan yang cermat, manajemen yang tepat, implementasi maksimal dan pengawasan berkelanjutan.

Arpinus, dkk, (2019: 115) melakukan penelitian yang menunjukkan bahwa manajemen kepala sekolah sangat diperlukan untuk mewujudkan sekolah yang memiliki budaya religius. Penelitian Arpinus, dkk, menunjukkan bahwa manajemen kepala sekolah dalam mewujudkan budaya agama dimulai dari perencanaan (program harian, program mingguan, program triwulanan, dan program semester). Kemudian pengorganisasian (pembagian tugas). Selanjutnya pelaksanaannya, yaitu tahfiz, menghafal hadits, azan, zikir, sholat, puasa sunnah, sholat dhuha, jemaah sholat tengah malam, buka bersama dan MABIT. Selanjutnya, pengawasan, pengawasan atau evaluasi yang dilakukan adalah pertemuan rutin setiap bulan dan melalui buku pribadi harian siswa.

Siswanto (2011: 47) menyatakan bahwa ada 7 komponen manajemen madrasah agar madrasah dapat dikelola dengan baik yaitu: manajemen kurikulum dan pengajaran, manajemen tenaga kependidikan, manajemen peserta didik (kesiswaan), manajemen keuangan dan pembiayaan, manajemen sarana dan prasarana, manajemen hubungan madrasah dan masyarakat, manajemen layanan khusus.

Hasan Zaini (2013: 1), menguraikan bahwa terdapat ayat al Qur'an yang menunjukkan konsep manajemen. Manajemen adalah fondasi Islam, Qur'an dan Hadits dengan prinsip tauhid, khalifah dan amanah. Lebih jauh, fungsi yang secara populer disebut perencanaan, pengorganisasian, penggerak dan pengendalian, sejalan dengan ajaran $\mathrm{Al}$ Qur'an, bahwa dalam kehidupan dan kehidupan, manusia harus memiliki perencanaan, pengorganisasian, persatuan dan kerja sama yang saling menguntungkan. Selain itu harus juga bisa menggerakkan 
orang lain untuk berbuat baik dalam bentuk motivasi, saran dan bimbingan. Maka perlu dikontrol dan dimonitor untuk mendapatkan hasil yang maksimal.

MTsN Padang Panjang menjadi salah satu madrasah yang memiliki banyak prestasi, baik tingkat kota Padang Panjang, tingkat Provinsi Sumatera Barat, dan tingkat Nasional. Prestasi tersebut tidak hanya dalam bidang akademik atau mata pelajaran semata, melainkan juga dalam bidang keagamaan, olah raga, dan pengembangan bakat lainnya. Selain prestasi, antusias masyarakat untuk menyekolahkan anaknya ke MTsN Padang Panjang juga relatif tinggi. Jumlah calon siswa yang mendaftar setiap tahunnya ratarata mencapai 1000 orang, sementara yang diterima hanya sekitar 330 orang. Selain itu, lulusan MTsN Padang Panjang juga banyak yang diterima di MAN dan SMA favorit di Sumatera Barat dan nasional.

Penulis tertarik melakukan penelitian ini dikarenakan dari beberapa MTsN di Sumatera Barat, MTsN Kota Padang Panjang merupakan madrasah yang mampu menerapkan manajemen peserta didik sehingga dapat menjadikan peserta didiknya meraih prestasi dan madrasahnya sangat diminati. Penulis ingin mengetahui lebih lanjut terkait pengelolaan penerimaan peserta didik baru, orientasi peserta didik dan pembinaan peserta didik yang dilaksanakan di MTsN Padang Panjang. Berdasarkan uraian di atas, tujuan penelitian ini adalah untuk mengetahui strategi pengembangan manajemen peserta didik (penerimaan, orientasi, pembinaan) untuk meningkatkan mutu pendidikan di MTsN Padang Panjang.

\section{METODE PENELITIAN}

Penelitian ini dilaksanakan di MTsN (Madrasah Tsanawiyah Negeri) Padang Panjang dengan pendekatan kualitatif dengan tujuan mengenal data-data yang dikumpulkan melalui studi lapangan. Adapun jenis penelitiannya adalah studi kasus yaitu membahas strategi pengembangan manajemen peserta didik dalam meningkatkan mutu pendidikan di MTsN Padang Panjang. Dalam usaha mendapatkan data dan menemukan fakta tentang manajemen yang dilakukan pihak MTsN Padang Panjang, penulis mempergunakan instrumen dalam mengumpulkan data, seperti pedoman observasi, pedoman wawancara, pedoman dokumentasi, field notes, recorder dan lain-lain.

Sumber data dalam penelitian ini diperoleh dari buku-buku, majalah, koran dan lain-lain yang relevan dengan judul artikel sebagi informasi terhadap penelitian yang diteliti. Pemilihan informasi dalam penelitian ini adalah dengan teknik snowball sampling yaitu informasi kunci akan menunjuk orang yang mengetahui masalahmasalah yang akan diteliti untuk melengkapi keterangan-keterangan dan orang yang ditunjuk akan menunjuk orang lain, apabila keterangan yang diberikan kurang bisa memahami dan seterusnya. Teknik ini akan bermanfaat bagi peneliti sebagai validatasi data yang diberikan oleh informan. Data yang dikumpulkan terkait dengan penerimaan, orientasi, dan pembinaan peserta didik di MTsN Padang Panjang. 


\section{HASIL PENELITIAN DAN PEMBAHASAN}

Berdasarkan data sebelumnya dapat dikemukakan beberapa hasil penelitian, yaitu:

\section{Strategi Penerimaan Peserta Didik Baru}

Kebijakan operasional penerimaan peserta didik, juga memuat sistem pendaftaran dan seleksi atau penyaringan yang akan di berlakukan untuk peserta didik. Kebijakan penerimaan peserta didik ini dibuat berdasarkan kabupaten/kota. Petunjuk demikian harus dipedomani karena ia memang dibuat dalam rangka mendapatkan calon peserta didik sebagaimana yang diinginkan atau diidealkan (Ali Imron, 2015: 42).

Panitia penerimaan peserta didik baru (PPDB) MTsN Padang Panjang hanya menerapkan jalur seleksi dalam menerima peserta didik. Panitia PPDB MTsN tidak menyediakan jalur promosi, meskipun calon peserta didik tersebut memiliki prestasi atau keunggulan. Jalur seleksi yang diterapkan terdiri dari tiga tahapan, yaitu tahapan seleksi administrasi, tes praktek dan tes tertulis.

Tahapan pertama yang dilakukan dalam seleksi peserta didik baru adalah pemeriksaan administrasi. Tahapan kedua adalah tes membaca al Qur'an, hafalan al Qur'an dan praktek shalat. Tahapan terakhir adalah tes tertulis dengan materi: IPA,IPS, matematika, bahasa Indonesia dan PKN. Masing-masing materi tes tersebut memiliki bobot yang berbeda. Bobot nilai rapor adalah $20 \%$, bobot nilai praktek adalah $30 \%$ dan bobot nilai tes terlusil adalah $50 \%$. Setelah semua nilai dijumlahkan sesuai dengan bobot nilai tersebut, kemudian diurutkan sesuai dengan ranking, mulai dari yang tertinggi sampai yang terendah. MTsN hanya akan menerima 345 orang peserta didik baru, maka nomor urut 1 sampai 345 akan diterima sebagai peserta didik baru. Sementara yang nomor urut 346 sampai 350 akan menjadi cadangan. Calon peserta didik urutan berikutnya dinyatakan tidak diterima atau gugur.

MTsN Padang Panjang menerapkan ketiga macam kriteria penerimaan peserta didik baru. Kriteria pertama adalah kriteria acuan patokan (standard criteria referenced). Kriteria kedua adalah kriteria acuan normal. Kriteria ketiga, yaitu sesuai dengan daya tampung.

Pengumuman penerimaan peserta didik baru MTsN Padang Panjang disampaikan melalui beberapa cara, yaitu pertama melalui media internet website www.mtsnpadangpanjang.com, kedua melalui radio, dan penyebaran brosur. Cara pertama melalui website, MTsN Padang Panjang menampilakan profil madrasah, prestasi yang pernah diraih dan menampilkan pengumuman penerimaan peserta didik baru. Cara yang kedua adalah dengan membuat dan mencetak brosur PPDB MTsN Padang Panjang. Cara yang ketiga adalah melalui pengumuman radio $\mathrm{El}$ Embahana Padang Panjang. Radio mengumumkan tentang MTsN dan penerimaan peserta didik baru di MTsN selama 15 hari. MTsN hanya menggunakan 3 cara tersebut dikarenakan MTsN Kota Padang Panjang sudah relatif dikenal dan diminati oleh warga Sumatera Barat.

Pendaftaran calon peserta didik baru di MTsN Padang Panjang dilaksanakan 
mulai tanggal 21 Maret 2019 sampai tanggal 27 Maret 2019. Panitia PPDB telah berada di MTsN semenjak jam 07.30 hingga jam 16.00. Panitia PPDB yang bertugas menerima calon peserta didik baru bersama dengan orang tua mempersilahkan yang bersangkutan untuk menyerahkan syarat administrasi dan mengisi formulir pendaftaran. Setelah formulir pendaftaran diisi maka peserta didik akan mendapatkan nomor urut untuk dilakukan tahapan seleksi. Peneliti melampirkan form formulir penerimaan peserta didik baru MTsN Padang Panjang.

Pendaftaran melalui aplikasi on line mulai dilaksanakan pada tahun 2019. Agar bisa mendaftar on line, peserta didik terlebih dahulu men-download (mengunduh) aplikasi PPDB MTsN Padang Panjang. Pada aplikasi tersebut, peserta didik dapat mengisi biodata, meng-upload nilai rapor kelas V semester 1 dan 2 serta kelas VI semester 1. Apabila isian tersebut telah diselesaikan oleh calon peserta didik maka dapat langsung ditekan tampilan "mendaftar". Ketika calon peserta didik telah menekan tombol mendaftar maka yang bersangkutan dinyatakan telah terdaftar sebagai calon peserta didik MTsN Padang Panjang.

Setelah itu, calon peserta didik bersama orang tua/ wali datang ke sekolah untuk menyerahkan bukti pendaftaran on line dan mengambil nomor peserta ujian. Peserta didik diharuskan membawa rapor asli untuk ditunjukkan kepada panitia. Peserta didik yang berkeinginan mendaftar ke MTsN tanpa mendaftar on line maka tidak bisa diterima. Solusinya adalah peserta tersebut akan dibimbing mendaftar on line di
MTsN oleh Panitia Penerimaan Peserta Didik Baru. Kemudian, panitia memeriksa kelengkapan pendaftaran dan setelah dinyatakan memenuhi syarat maka panitia PPDB akan memberikan kartu peserta ujian.

Setelah calon peserta didik dinyatakan memenuhi persyaratan administrasi, maka calon peserta didik mendapatkan nomor ujian. Setelah itu, calon peserta didik mengikuti tes masuk. Tes dilakukan pada tanggal 30 Maret 2019 di MTsN Padang Panjang. Tes pertama adalah tes membaca al Qur'an, hafalan al Qur'an dan praktek shalat. Guru yang bertugas melaksanakan tes, menetapkan uraian penilaian pada masing-masing bagian tes, misalnya dalam tes membaca dan hafalan al Qur'an, petugas yang melakukan tes menilai tajwid, irama, kefasihan dan jumlah hafalan calon peserta didik. Tahapan berikutnya adalah tes tertulis dengan materi: IPA,IPS, matematika, bahasa Indonesia dan PKN.

Calon peserta didik yang akan tinggal di asrama madrasah diharuskan mengikuti tes masuk asrama. Tes dilakukan pada hari yang sama dengan tes praktek dan tertulis. Rapat Panitia PPDB MTsN Padang Panjang dipimpin oleh Ketua Panitia yang juga merangkap jabatan sebagai Wakil Kepala Madrasah Bidang Kesiswaan. Rapat dilakukan untuk menyajikan hasil tes, mendiskusikan dan menetapkan calon peserta didik baru yang akan diterima dan yang akan dijadikan sebagai calon peserta didik cadangan. Rapat dilaksanakan pada hari Jum'at, 5 April 2019. Pengumuman calon peserta didik baru yang diterima dan yang dijadikan cadangan dilaksanakan pada hari Ahad, 7 April 2019. Jumlah peserta 
didik yang diterima disesuaikan dengan daya tampung MTsN. Pengumuman calon peserta didik yang diterima disampaikan melalui website MTsN Padang Panjang dan panitia PPDB akan mengirimkan hasilnya ke email masing-masing calon peserta didik.

Pendaftaran ulang peserta didik baru MTsN Padang Panjang dilakukan dengan ketentuan sebagai berikut: Calon peserta didik membawa kartu asli peserta ujian, Menyerahkan pas foto calon peserta didik dan pas foto kedua orang tua masingmasing 2 x 3 sebanyak 3 lembar dan $3 \times 4$ sebanyak 3 lembar, Foto copy akte kelahiran dan kartu keluarga, Foto copy rapor 3 semester yang telah dilegalisir, Foto copy KTP kedua orang tua, Foto copy SKTM (Surat Keterangan Tidak Mampu) jika berasal dari keluarga tidak mampu, Foto copy PKH (Program Keluarga Harapan) jika ada.

\section{Strategi Orientasi Peserta Didik}

Tujuan diadakan orientasi bagi peserta didik baru adalah agar siswa mengenal lebih dekat dirinya di tengahtengah lingkungan baru, supaya mengenal lingkungan sekolah, baik lingkungan fisiknya maupun lingkungan sosial, menyiapkan siswa secara fisik, mental dan emosional, peserta didik dapat mengerti dan mentaati peraturan yang berlaku di sekolah, supaya peserta didik lebih aktif dalam kegiatan sekolah, agar peserta didik betah di sekolah (Asmendri, 2014: 54).

Orientasi peserta didik baru yang dilaksanakan di MTsN Padang Panjang disebut dengan Matsama (Masa Ta'aruf Siswa Madrasah). Kegiatan Matsama dilaksanakan selama 3 hari, mulai dari 15 Juli - 17 Juli 2019 di MTsN Padang Panjang. Materi Matsama adalah yang berkaitan dengan pengenalan lingkungan MTsN Padang Panjang, dan lainnya.

Tujuan pelaksanaan Matsama MTsN Padang Panjang adalah sebagai berikut: Pertama, Memperkenalkan lingkungan MTsN bagi siswa baru, Kedua, Memperkenalkan sistem belajar di MTsN, Ketiga, Mempererat silaturrahmi masing masing tingkat antara kelas 7,8, dan 9, Keempat, Memberikan kesempatan kepada peserta didik untuk mengelola kegitan di MTsN, Kelima, Mengembangkan kemampuan kepemimpinan kepada peserta didik.

Panitia Matsama terdiri dari wakil kepala madrasah bidang kesiswaan, beberapa orang pendidik dan tenaga kependidikan, serta pengurus OSIM. Pengurus OSIM menjadi pelaksana teknis di lapangan, sementara wakasis dan guru serta tenaga kependidikan bertugas untuk memberikan arahan/ bimbingan dan menjadi pemateri/ nara sumber kegiatan. Materi Matsama adalah yang berkaitan dengan pengenalan lingkungan MTsN Padang Panjang. Materi utama adalah mengenalkan pendidik dan tenaga kependidikan yang ada di MTsN, mengenal sarana dan prasana atau fasilitas pendidikan yang ada di MTsN dan mengenal kakak tingkat/ pengurus OSIM. Materi utama berikutnya adalah mengenai sistem pembelajaran yang ada di MTsN dan latihan upacara, baris berbaris dan lainnya.

Selain kegiatan pengenalan MTsN, peserta didik baru juga mendapatkan 
bimbingan ibadah, seperti shalat dhuha secara bersama-sama, dan tahsin bacaan al Qur'an. Selain itu, peserta didik yang mengikuti Matsama juga mendapatkan materi outbond dan games. Kegiatan outbond dan games dilakukan untuk meningkatkan keakraban antar peserta didik dan meningkatkan kematangan sosial peserta didik. Terkait dengan kegiatan Matsama MTsN Padang Panjang, peneliti melampirkan jadwal kegiatan Matsama 2019/ 2020.

\section{Pembinaan Peserta Didik}

Pembinaan peserta didik dilakukan melalui kegiatan kurikuler atau ekstra kurikuler. Kegiatan kurikuler adalah semua kegiatan yang telah ditentukan dalam kurikulum yang pelaksanaannya dilakukan pada jam-jam pelajaran. Kegiatan kurikuler dalam bentuk proses belajar mengajar di kelas dengan nama mata pelajaran dan bidang studi yang ada disekolah. Sementara, kegiatan ekstrakurikuler adalah kegiatan peserta didik yang diselenggarakan oleh madrasah namun di luar jam pelajaran.

Kegiatan kurikuler yang dilaksanakan di MTsN Padang Panjang adalah sebagai berikut: Kegiatan pembelajaran atau PBM (Proses Belajar Mengajar). Kegiatan PBM dilaksanakan mulai dari hari Senin hingga hari Sabtu. Pada hari Senin - Kamis, peserta didik mengikuti PBM pada jam 07.30 - 15.30 WIB. Pada hari Jumat, peserta didik mengikuti PBM pada jam 07.30 - 11.50 WIB. Pada hari Sabtu, peserta didik mengikuti pada jam 07.30 - 12.30 WIB. Mata pelajaran berjumlah 17 mata pelajaran. Guru berjumlah 73 orang, dan tenaga kependidikan berjumlah 19 orang. Lebih lanjut terkait dengan kegiatan kurikuler, peneliti melampirkan jadwal mata pelajaran berserta dengan pendidiknya. Kegiatan pramuka yang dilaksanakan pada jam pelajaran reguler. Kegiatan pramuka dilaksanakan sebanyak 1 kali seminggu yang diikuti oleh 6 lokal paralel. Pemateri kegiatan pramuka didatangkan dari pembina pramuka kota Padang Panjang dengan bimbingan dari guru MTsN Padang Panjang. Kegiatan tahfiz al Qur'an. Kegiatan tahfiz al Qur'an dilaksanakan setiap minggu sebanyak 1 (satu) jam pelajaran. Kegiatan tahfiz al Qur'an dibimbing oleh guru MTsN Padang Panjang.

Pembinaan kurikuler di MTsN Padang Panjang dilaksanakan melalui proses pembelajaran yang dilakukan masing-masing guru kelas. Pembinaan kurikuler dilaksanakan dalam keseluruhan kegiatan peserta didik ketika jam-jam pembelajaran di sekolah atau kegiatan proses pembelajaran. Pembinaan kurikuler dalam proses pembelajaran, dibagi menjadi 3 (tiga) kegiatan, yaitu: kegiatan pendahuluan, kegiatan inti, dan kegiatan penutup. Ekstrakurikuler adalah kegiatan non pelajaran formal yang dilakukan peserta didik sekolah/ madrasah, umumnya di luar jam belajar kurikulum standar. Kegiatan ini diadakan secara swadaya dari pihak sekolah maupun siswa siswinya itu sendiri. Kegiatan ekstrakurikuler di tujukan agar siswa dapat mengembangkan kepribadian, bakat dan kemampuannya di berbagai bidang di luar bidang akademik 
seperti seni, olahraga dan pengembangan kepribadian lainnya.

Kegiatan ekstrakurikuler di MTsN terlaksana dengan baik dan beragam. Hal tersebut selaras dengan pendapat Aldjon Dapa, dkk mengemukakan kegiatan ekstrakurikuler merupakan suatu kegiatan yang secara kurikuler tidak diatur, akan tetapi perlu dilaksanakan dalam rangka mempertinggi rasa sosial keagamaan, sosial budaya, pengembangan kegemaran, ataupun dapat berupa kepramukaan, kelompok atau regu kesenian, olahraga dan kesehatan (Aldon S Dapa, dkk, 2007: 92)

Kegiatan ekstrakurikuler yang dilaksanakan di MTsN Padang Panjang adalah sebagai berikut: Pertama, belajar tambahan. Kegiatan belajar tambahan dilakukan dengan dua bentuk yaitu terstruktur dan tidak terstruktur. Kegiatan belajar tambahan yang terstruktur dilaksanakan pada hari Jumat dan Sabtu, mulai dari jam 2 sampai jam 4 sore. Materi pelajarannya adalah selain dari olahraga, prakarya, tahfiz, pramuka, seni dan budaya. Belajar tambahan terstruktur diwajibkan untuk kelas 9. Kegiatan belajar yang tidak terstruktur atau les tidak dikelola oleh MTsN, namun dilaksanakan di madrasah. Kegiatan les ini dilatarbelakangi oleh keinginan orang tua agar anaknya mendapatkan materi tambahan dari guru di madrasah. Kedua, kegiatan tahfiz al Qur'an. Selain pada jam pelajaran reguler, kegiatan tahfiz al Qur'an juga dilaksanakan pada waktu yang lain/ di luar jam pelajaran reguler. Ketiga, pembinaan di asrama. Peserta didik yang berasal dari luar Kota Padang Panjang dan berkeinginan untuk tinggal di asrama, dapat mengikuti seleksi masuk asrama. Kepala asrama merangkap kepala asrama wanita adalah Ibu Erniwita, S.Pd.I yang merupakan guru bahasa arab. Penanggung jawab asrama putra adalah Wendra Hanafi, S.Pd yang merupakan guru olah raga. Pembimbing asrama putra berjumlah 6 orang dan pembimbing putri berjumlah 6 orang. Kepala asrama wajib tinggal di asrama, sehingga dapat mengkontrol dan membimbing peserta didik. Selama di asrama, peserta didik mengikuti berbagai kegiatan pembinaan ibadah dan akhlak, seperti kegitan tahsin dan tahfiz al Qur'an, murajaah hafalan al Qur'an, pelatihan pidato, pengajian/ kajian agama, shalat berjamaah di mushalla, serta bimbingan pelaksanaan ibadah sunnah seperti puasa sunnah dan shalat tahajjud.

Urutan kegiatan peserta didik di asrama adalah sebagai berikut:

a. Peserta didik pulang dari MTsN ke asrama sekitar jam 17.30 (jam 5.30 sore). Sebelumnya peserta didik mengikuti kegiatan belajar, belajar tambahan dan kegiatan olah raga.

b. Menjelang maghrib, masing-masing peserta didik melakukan kegiatan pribadi, seperti mencuci, istirahat, mandi dan lain sebagainya.

c. Peserta didik mengikuti shalat maghrib berjamaah di mushalla

d. Peserta didik mengikuti kegiatan menjelang masuknya waktu isya. Kegiatan tersebut dilaksanakan di dalam mushalla. Kegiatan tersebut di antaranya adalah berzikir, berdoa, membaca al Qur'an, menghafal al Qur'an, mengulang dan menyetorkan 
hafalan al Qur'an, kajian dan bimbingan praktek ibadah, dan lainnya.

e. Peserta didik melaksanakan shalat Isya berjamaah dan dilanjutkan dengan berzikir dan berdoa serta shalat sunnah.

f. Setelah shalat isya peserta didik makan bersama.

g. Peserta didik belajar di ruangannya masing-masing hingga jam 22.00 WIB (10 malam). Selama sekitar 2,5 jam, peserta didik mengulang pelajaran, mengerjakan tugas, berdiskusi, bercengkrama, dan membaca buku.

h. Peserta didik tidur hingga jam 04.00 WIB (jam 4 pagi).

i. Peserta didik berwudhu atau mandi dan melaksanakan shalat tahajjud

j. Pada hari yang disunnahkan berpuasa, biasanya peserta didik makan sahur bersama-sama dengan pembina asrama, terutama pada hari Senin dan Kamis. Setelah shalat tahajjud, peserta didik mengambil nasi untuk makan sahur bersama.

k. Shalat subuh berjamaah di mushalla

1. Membaca al Qur'an, dan menghafal al Qur'an dan mempersiapkan diri untuk belajar di MTsN

m. Pada jam 06.30 WIB peserta didik mulai berangkat menuju ke MTsN.

Keempat, pembinaan olah raga. MTsN Padang Panjang melaksanakan pembinaan olah raga yang dilaksanakan secara rutin. Pelatih/ pembimbing olah raga tersebut adalah guru yang berasal dari MTsN Padang Panjang. Olah raga yang rutin dibimbing adalah olah raga bola basket dan bola voli. Latihan olah raga bola voli dilaksanakan setiap hari Senin dan Kamis. Tempat latihannya di dalam lingkungan MTsN Padang Panjang. Selain bola basket dan bola voli, olah raga bola kaki juga ada dilatih oleh guru khusus namun hanya dilaksanakan menjelang adanya kompetisi bola kaki.

Olah raga basket merupakan salah satu olah raga yang paling banyak mendapatkan prestasi. Tim basket MTsN Kota Padang Panjang merupakan salah satu tim basket terbaik di Sumatera Barat. Prestasi yang diraih oleh peserta didik tersebut dikarenakan MTsN melakukan pembinaan olah raga bola basket dan dilatih oleh pelatih yang berkompeten. Pelatih olah raga bola basket MTsN adalah Wendra Hanafi. Wendra Hanafi merupakan guru bidang studi olah raga, tamatan fakultas ilmu keolahragaan UNP, memiliki lisensi C sebagai pelatih (coach) basket, pernah menjadi pelatih tim basket putri Sumatera Barat dan pernah menjadi pelatih POPNAS (Pekan Olah Raga Nasional) di Jakarta. Latihan dilaksanakan setiap hari rabu dan jum'at, mulai jam 15.45 WIB hingga jam 17.30 WIB. Pelatih menekankan fundamental skill sehingga kemampuan dasar peserta didik menjadi sangat baik. Selain latihan, pelatih juga sering mengadakan uji coba tanding dengan tim basket lain, misalnya dengan tim basket SMAN 2 Padang Panjang dan SMP Adabiah Padang. Uji tanding dilakukan untuk melatih mental dan memperhatikan kelemahan tim basket. 
Setelah uji tanding, pelatih mengetahui sisi kelemahan peserta didiknya, sehingga evaluasi dan perbaikan dapat dilakukan dengan tepat. Selain itu, pelatih juga mengedepankan kekompakan, keseriusan, kedisiplinan dan memunculkan rasa cinta kepada olah raga bola basket.

Keberhasilan pembinaan dan pengembangan peserta didik diukur melalui proses penilaian yang dilakukan oleh lembaga pendidikan (oleh guru). Ukuran yang sering digunakan adalah naik kelas dan tidak naik kelas bagi peserta didik yang belum mencapai tingkat akhir serta lulus dan tidak lulus bagi peserta didik yang tingkat akhir sebuah lembaga pendidikan (sekolah). penilaian yang dilakukan oleh guru tentu saja berdasarkan prinsip-prinsip penilaian yang berlaku di lembaga pendidikan (sekolah) tersebut.

Keberhasilan pembinaan dan pengembangan peserta didik di MTsN Padang Panjang diketahui dari beberapa hal, yaitu: pertama, tidak ada peserta didik yang tidak tamat/ lulus dari MTsN, kedua, setiap tahunnya, tidak ada peserta didik yang tinggal kelas, ketiga, setiap tahunnya, nilai rata-rata mata pelajaran peserta didik relatif tinggi, keempat, peserta didik memiliki prestasi, baik di bidang akademik maupun di bidang non akademik, kelima, peserta didik yang tamat dari MTsN Padang Panjang banyak yang diterima di Sekolah Menengah Atas (SMA) dan Madrasah Aliyah (MA) favorit di Sumatera Barat.

\section{PENUTUP}

\section{Kesimpulan}

Berdasarkan temuan penelitian yang peneliti lakukan maka dapat disimpulkan bahwa: MTsN Padang Panjang menerapkan penerimaan peserta didik secara profesional, terstruktur dan sistematis. Hal ini dilaksanakan untuk meningkatkan mutu pendidikan madrasah. Panitia PPDB menetapkan seleksi yang relatif ketat untuk meningkatkan kualitas peserta didik yang akan mengikuti pendidikan di MTsN Padang Panjang. MTsN Padang Panjang menyelenggarakan orientasi yang dilaksanakan dengan melibatkan pendidik, tenaga kependidikan, dan pengurus OSIM. Orientasi peserta didik baru dinamakan dengan Matsama (Masa Ta'aruf Siswa Madrasah). Matsama dilaksanakan selama 3 (tiga) hari. Matsama bertujuan untuk mengenalkan lingkungan MTsN, menjalin silaturahim/ keakraban antar siswa dan meningkatkan motivasi belajar. MTsN Padang Panjang melaksanakan pembinaan dan pengembangan peserta didik dalam upaya meningkatkan mutu pendidikan. Pembinaan dan pengembangan peserta didik dilakukan dalam bidang akademik/ mata pelajaran dan non akademik. Pembinaan dan pengembangan peserta didik dilakukan dengan keikutsertaan seluruh warga MTsN bersama dengan orang tua/ wali siswa.

\section{Saran}

Berdasarkan kesimpulan dari penelitian ini, diberikan saran kepada warga MTsN Padang Panjang agar tetap 
komitmen dalam menerapkan aturan yang telah disepakati dan ditetapkan, baik dalam hal penerimaan peserta didik baru, orientasi peserta didik dan pembinaan pengembangan peserta didik. Saran kepada masyarakat Kota Padang Panjang dan sekitarnya, agar menjaga, mendukung usaha pihak MTsN dan merasa bangga. Saran kepada MTsN lain, hendaknya dapat mempelajari dan menjadikan MTsN Padang Panjang sebagai salah satu madrasah tsanawiyah negeri yang mampu sukses dalam mengembangkan pendidikan peserta didiknya. Saran kepada peneliti berikutnya, peneliti mengusulkan kepada peneliti berikutnya untuk melakukan penelitian dalam hal yang lain, misalnya terkait dengan manajemen pendidik, manajemen tenaga kependidikan, dan manajeman sarana dan prasarana.

\section{KEPUSTAKAAN ACUAN}

Arpinus, dkk, 2019, Manajemen Kepala Sekolah dalam Mewujudkan Budaya Religius di Sekolah Dasar Islam Terpadu Ar-Rahman Palangki, Jurnal Al Fikrah Manajemen Pendidikan, Vol 7, No. 2, http://ecampus.

iainbatusangkar.ac.id/ojs/index.php/ alfikrah/article/view/1595

Asmendri, dke.., 2019, Manajemen Prinsip Madrasah di MA KMM Kauman Padang Panjang dalam Melaksanakan Program Adiwiyata", Proceeding Batusangkar International Conference III, Graduate Programme of IAIN Batusangkar. ISBN: 978-602-329-074-1, bhttp://ecampus.iainbatusangkar. ac.id/ojs/index.php/proceedings/art icle/view/1542

Asmendri, 2014, Manajemen Peserta Didik (Teori, Praktek, Dan Riset Pendidikan), Batusangkar: STAIN Batusangkar Press

Fadriati, 2018, Model Total Quality Management Pada Lembaga Pendidikan Islam, Proceeding LAIN Batusangkar, Vol.3, No. 1, http://ecampus.iainbatusangkar.ac.id /ojs/index.php/proceedings/article/ view/1294 2019

Fitri, Agus Zaenul, 2013, Manajemen Kurikulum Pendidikan Islam, Bandung: Alfabeta

Hendriani, Suswati dkk, 2017, Pengarub Kecerdasan Emosional dan Kepemimpinan Terhadap Kepemimpinan Kepala Madrasah di Kabupaten Agam,http:/ / ecampus.iainbatusangka r.ac.id/ojs/index.php/alfikrah/article /view/159

Imron, Ali, 2015, Manajemen Peserta Didik Berbasis Sekolah, Jakarta: Bumi Aksara Maimun, Agus dan Fitri, Agus Zainul, 2010, Madrasah Unggulan, UIN Maliki Press

Sastrohadiwiryo, Siswanto, 2011, Manajemen Tenaga Kerja Indonesia, Pendekatan Administrative dan Operasional Jakarta: PT Bumi Aksara

Zahroh, Aminatul, 2014, Manajemen Sekolah Unggulan: Strategi Pengembangan 
Kapasitas Sekolah Menuju Pendidikan Bermutu, Ta'allum Jurnal Pendidikan Islam, Vol. 2, No. 2, http:/ / ejournal.iain-tulungagung.ac.id

Zaini, Hasan, 2013, Manajemen Pendidikan dalam Perspektif Al Qur'an, Al Fikrah
Jurnal Manajemen Pendidikan, Vol. 1, No.

http://ecampus.iainbatusangkar.ac.id /ojs/index.php/alfikrah/article/view /346 2016

106 | Jurnal al-Fikrah, Vol. VIII, No. 2 Juli-Desember 2020 